\title{
Water quality and micro-organisms of leachate-contaminated pond
}

\author{
Agatha A. Nwabueze
}

\author{
Department of Fisheries, Delta State University, Asaba Campus, Asaba, Nigeria.
}

\begin{abstract}
The physical and chemical analyses of leachate and leachate-contaminated pond water were investigated. Leachate was observed to have significantly $(P<0.05)$ high levels of biochemical oxygen demand (BOD), chemical oxygen demand (COD), $\mathrm{pH}$ and alkalinity than water samples from the three stations of study. Dissolved oxygen (DO) level was significantly lower $(P<0.05)$ in the leachate sample followed by station I, which is the major point of entry of leachate into the pond. DO in station I was not significantly lower $(P>0.05)$ than DO levels recorded for stations I and II. This study has shown the possibility of leachate contamination of water bodies from near by waste dump sites. Leachate exerted negative impact on water quality parameters of the pond which were either elevated or reduced to acceptable but stressful levels for fish production especially in station I. Pond water was also found to be contaminated with micro-organisms, some of which have public health implications. There is a need for strict legislation on environmental waste management against the siting of waste dumps near water bodies. This will prevent the possible transfer of contaminants from leachate- polluted waters by fish to man.
\end{abstract}

Keywords: leachate, water quality, micro-organisms, fish, ponds.

\section{INTRODUCTION}

The lack of proper management of solid wastes is a major environmental issue in Nigeria. Ojolo et al. (2004) reported the annual generation of municipal solid waste in Nigeria as $29.78 \times 10^{9} \mathrm{~kg}$. This value may increase due to increase in urbanization and population growth. Solid wastes are normally disposed off in uncontrolled and improperly sited open dumps located in public places. Leachate according to Wikipedia (2010), is any liquid that in passing through matter, extracts solutes, suspended solids or any other component of material through which it has passed introducing environmentally harmful substances which may enter the environment. The composition of leachate varies widely depending on the age of the landfill and the type of solid waste it contains. The physical and chemical compositions of leachate have been characterized (Yasuhara et al.1997, 1999; Ikem et al. 2002). Waste disposal sites are capable of releasing large amount of harmful chemicals to nearby water sources and air via leachate and landfill gases respectively (Christensen et al. 2001; Alimba et al. 2006). In addition to toxic elements, leachate may contain microbes which may be pathogenic producing toxins capable of causing public health hazards (Donnelly et al. 1988).

Leachate being a complex mixture of organic, inorganic and many unidentified toxicants may pose risk of unknown magnitude to aquatic life. The effect of leachate on water quality parameters is enormous. Leachate can cause increase in turbidity of water, limiting the amount of light penetration which reduces photosynthesis and production of dissolved oxygen (Pillay, 1992). Leachate has also been reported to increase water alkalinity and hardness (Dupree and Huner, 1984). Bakare and Wale-Adeyemo (2004) reported various types of chromosomal aberration due to presence of leachate in Allium cepa. Changes in heamatological parameter of fish reared in leachate-contaminated water have also been reported (VanVuren, 2006). Leachate may clog fish gills reducing resistance to diseases, lowering growth rate and affecting egg and larval developments (Ovre and Adeniyi, 1990).

Studies on the possible health hazards of solid waste leachate and its effect on aquatic organisms have been conducted (Wong, 1989; Ernst et al. 1994; Bernard et al. 1996; Wick and Dave, 2006; McMurphy et al.1996; Koshy et al. 2007). Several unapproved solid waste dump sites exist in Asaba and environs. Some of these dump sites are located close to water bodies. Aquatic organisms especially fish may be affected by leachate due to its ability to alter water quality and introduce pathogens into water. In Nigeria, there is paucity of information on the effects of domestic leachate on the aquatic ecosystem. This study investigates the water quality and micro-organisms of domestic leachatecontaminated pond in Asaba. 


\section{MATERIALS AND METHODS}

Domestic leachate from the Cable dump site in Asaba, Nigeria was used for this study which lasted from March to December, 2009. Asaba is located on longitude $6^{0} 11^{\prime} \mathrm{E}$ and latitude $6^{\circ} 45^{\prime} \mathrm{N}$. The dump site situated in Cable point is on the bank of one of the natural depression ponds along the area liable to flooding of the River Niger at Asaba. The pond supplies fish for fisher folks and fish consumers in the area. Leachate samples were collected using sterile stainless steel buckets while water samples were collected from the pond in clean five litre plastic containers fortnightly throughout the period of study and transported to the laboratory for analyses of physical and chemical properties as well as for presence of micro- organisms. Water samples were collected from three different stations at the pond.

Station I is the major point of entry of leachate into the pond while stations II and III are approximately $200 \mathrm{~m}$ and $380 \mathrm{~m}$ away from station I respectively. Water quality parameters were determined according to APHA (1985). Microbial analysis was done by isolating, culturing and identifying of isolates in the leachate- contaminated pond water following the method of Olutola et al. (2002). Pond water samples were also centrifuged and examined under the microscope for protozoal contents. Seasonal variation (dry: October- December and rainy : MarchJuly) in levels of water quality parameters were investigated. Data obtained were subjected to analysis of variance at $\mathrm{P}=0.05$ level of significance. While significant means were separated using Duncan Multiple Range Test (DMRT).

\section{RESULTS AND DISCUSSION}

The physical and chemical characteristics of domestic waste leachate and pond water samples for dry and rainy seasons are presented on tables 1 and 2. Waste leachate from domestic waste dump site studied was yellowish-brown in colour $(10 \mathrm{~Hz})$ with offensive odour. Leachate from typical landfill has been characterized by strong odour with black, yellow or orange coloured cloudy liquid. The smell may be acidic and offensive and may be pervasive because of hydrogen, nitrogen and sulphur rich organic species (Wikipedia, 2010). Temperature was slightly higher in the dry season in all the stations than in rainy season. Leachate was observed to have high levels of biochemical oxygen demand (BOD) and chemical oxygen demand (COD). BOD and COD were significantly $(P<0.05)$ higher in the leachate water than in the water samples from the three stations of study. This finding is similar to the report of Ehrig (1983), who found that with anaerobic acetic production volatile fatty acids produced in leachate have higher BOD and COD. Dissolved oxygen (DO) level was significantly $(P<0.05)$ lower in the leachate sample followed by station I, which is the major point of entry of leachate into the pond. DO in station I was not significantly $(P>0.05)$ lower than DO levels recorded for stations I and II. Boyd and Lichtkoppler (1979) reported that fish may survive but with slower growth rate with prolonged exposure in water with DO level of $1 \mathrm{mg} / \mathrm{l}$. The low dissolved oxygen level observed may not cause immediate fish kill but is capable of inducing stress to the fish with prolonged exposure. Alkalinity was high in the leachate and higher in station I than in the other stations. High alkalinity has a high buffering capacity than water with low alkalinities. Dupree and Huner, (1984) reported that alkalinities of 30 to $150 \mathrm{mg} / \mathrm{l}$ are preferred in fish culture. Although the effects of leachate may be weakened with distance from source of generation, it can still cause pollution of surface and ground water resulting in eutrophication of surface water (Robinson, 1983).

Table 1: Physicochemical characteristics of domestic leachate and pond water samples for dry season.

\begin{tabular}{|l|c|c|c|c|}
\hline Parameters & Leachate & & Stations & \\
\hline & & $\mathrm{I}$ & $\mathrm{II}$ & $\mathrm{III}$ \\
\hline Colour (Hz) & 06 & 05 & 05 & 04 \\
\hline $\begin{array}{l}\text { Temperature } \\
\left({ }^{0} \mathrm{C}\right)\end{array}$ & 34.2 & 30.3 & 29.0 & 29.7 \\
\hline $\mathrm{pH}$ & 8.1 & 7.6 & 7.5 & 7.2 \\
\hline $\mathrm{DO}(\mathrm{mg} / \mathrm{l})$ & 1.2 & 2.4 & 2.6 & 2.7 \\
\hline $\mathrm{BOD}(\mathrm{mg} / \mathrm{l})$ & 261.1 & 182.0 & 120.7 & 98.5 \\
\hline COD ( mg/l) & 230.4 & 156.3 & 103.2 & 54.6 \\
\hline $\begin{array}{l}\text { Alkalinity } \\
\text { (mg/l) }\end{array}$ & 8.8 & 8.2 & 7.8 & 7.8 \\
\hline $\begin{array}{l}\text { Turbidity } \\
\text { (n.t.u) }\end{array}$ & - & 48 & 42 & 35 \\
\hline
\end{tabular}

Source: Field survey (2009).

The micro-organisms isolated and identified were Escherichia coli, Pseudomonas flourescens, Streptococcus feacalis, Salmonella species, Staphylococcus aureus, Bacillus species, Flavobacterium species, Saprophytic spores and 
Table 2: Physico-chemical characteristics of domestic leachate and pond water samples for rainy season.

\begin{tabular}{|r|c|c|c|c|}
\hline Parameters & Leachate & & Stations & \\
\hline & & I & II & III \\
\hline Colour (Hz) & 10 & 06 & 05 & 05 \\
\hline $\begin{array}{r}\text { Temperature } \\
\left({ }^{0} \mathrm{C}\right)\end{array}$ & 31.3 & 30.4 & 29.6 & 30.0 \\
\hline $\mathrm{pH}$ & 8.9 & 7.8 & 7.2 & 7.3 \\
\hline $\mathrm{DO}(\mathrm{mg} / \mathrm{l})$ & 1.8 & 2.6 & 3.7 & 4.9 \\
\hline $\mathrm{BOD}(\mathrm{mg} / \mathrm{l})$ & 150.2 & 138.4 & 116.2 & 104.3 \\
\hline $\mathrm{COD}(\mathrm{mg} / \mathrm{l})$ & 288.2 & 212.2 & 210.1 & 208.1 \\
\hline $\begin{array}{r}\text { Alkalinity } \\
(\mathrm{mg} / \mathrm{l})\end{array}$ & 9.5 & 8.6 & 8.3 & 8.2 \\
\hline $\begin{array}{r}\text { Turbidity } \\
\text { (n.t.u.) }\end{array}$ & - & 64 & 50 & 44 \\
\hline
\end{tabular}

Source: Field survey (2009).

unidentified flagellated protozoa. Donnelly et al.(1988) reported that leachate may contain microbes some of which may be opportunistic pathogens and that these microbes are capable of producing toxins of public health concern. Micro-organisms contaminating water bodies via leachate are a potential threat to aquatic ecosystems and public health. Increased population of bacteria such as E.coli, P. florescens, S. faecalis and Klebsiella pneumoniae have been reported from landfill leachate sites (Donnelly and Scarpino, 1984; Obbard, 1999; Bakare et al. 2003b). Table 3 shows the spread of micro organisms in the leachate and pond water samples from the three stations studied. A higher microbial load was observed in the rainy season than the dry season. It has been noted that during the rainy season more water percolate through the waste promoting and assisting the process of decomposition by bacteria and fungi. This process has been known to release by-products of decomposition and rapidly use up any available oxygen creating an anoxic environment (Christensen, 1987). The risks from waste leachate are due to its high concentration of organic contaminants. When leachate enters the pond, the original transparent water becomes turbid due to many particles suspended in it. Leachates are not good for fish culture because they make the fish pond water turbid and reduce light penetration resulting in unavailability of natural fish food and production of dissolved oxygen. Survival of fish populations in leachatecontaminated water may be reduced. Benthic organisms in the water may equally be affected by leachate pollution.

Table 3: Micro-organisms in leachate and pond water samples

\begin{tabular}{|l|l|l|l|l|}
\hline Micro-organisms & Leachate & & Stations & \\
\hline & & I & II & III \\
\hline Escherichia coli & E. coli & E. coli & E. coli & E. coli \\
\hline P. flourescens & P. flourescens & P. flourescens & P. flourescens & P. flourescens \\
\hline Streptococcus feacalis & S. feacalis & S. feacalis & S. feacalis & S. feacalis \\
\hline Salmonella species & Salmonella sp. & - & - & - \\
\hline Staphylococcus aureus & - & - & - & S. aureus \\
\hline Bacillus species & Bacillus & Bacillus & - & - \\
\hline Flavobacterium species & - & - & - & Flavobacterium sp. \\
\hline Saprophytic spores & Sap. Spores & Sap. spores & Sap. spores & Sap. spores \\
\hline $\begin{array}{l}\text { (Sap.spores) } \\
\text { Unidentified Flagellated } \\
\text { Protozoa (UFP) }\end{array}$ & UFP & UFP & - & UFP \\
\hline
\end{tabular}

Source: Field survey (2009)

This study has shown the possibility of leachate contamination of water bodies from nearby waste dump sites. Leachate also exerted negative impart on water quality parameters of the pond of study. Dissolved oxygen levels were reduced. BOD, COD, alkalinity and $\mathrm{pH}$ levels were increased to unsuitable levels for fish production especially in station I which was closest to and point of entry to the waste dump site studied. Pond water was also contaminated with micro-organisms, some of which have public health implications. There is a need for strict legislation on environmental waste management against the siting of waste dumps near water bodies. This will prevent the possible transfer of contaminants from leachatepolluted waters by fish to man.

\section{REFERENCES}

Alimba, C.G., Bakare, A.A. and Latunji, C.A.(2006). Municipal landfill leachates Induced chromosome aberrations in rat bone marrow cells. Afri. J. Biotech. 5 (22): 2053-2057.

APHA (1985). Standard methods for examination of water and waste water. American Public Health Association. $16^{\text {th }}$ Edition, Washington.

Bakare, A.A.,Lateef, A., Amuda,O.S. and Afolabi, R.O. (2003b). The aquatic toxicity and characterization of chemical 
and microbiological constituentsof water samples from Oba River, Odo-Oba, Nigeria. Asian JR. Microbiol.Biotech.Enciron. Sci., 5 (1): 11-17.

Bakare, A.A.and Wale-Adeyemo, A.R. (2004). The mutagenic and cytotoxic effects Of leachate from domestic solid wastes and Aba-Eku landfill, Nigeria on Allium cepa. Nature Environ.Pollut.Tech., 3(4):455-462.

Bernard, C., Guido, P., Colin, J. and Du-Delepierre-A-le (1996). Estimation of Hazards of landfills through toxicity testing of leachates. Determination of leachate toxicity with a battery of acute tests. Chemosphere, 33(11): 2303-2324.

Boyd, C.E. and Lichtkoppler, F. (1979). Water Quality Management in Pond fish culture. International centre for Aquaculture, Agricultural Experimentation station. Auburn University Research Development series No. 22. Project AID/DSANG.0039.

Christensen, T.H. (1987). Cadmium soil absorbtion at low concentration $\mathrm{VI}, \mathrm{A}$ model for zinc competition. Water and Air and Pollution, 34 (3):

Christensen,T.H., Kjeidsen,P.,Bjeng,P.L.,Jensen, D.L., Christensen,J.B. Baun,A., Albrechtsen,H. and Heron, G. (2001). Biogeochemistry of landfill Leachateplumes. Appl. Geochem, 16:659-718.

Donnelly, J.A. and Scarpino, P.V. (1984). Isolation, characterization and identification of micro-orgnisms from laboratory and full scale landfills. Cincinnati Oh: US Environmental Protection Agency, municipal and environmental research laboratory, Office of research and development Publication EPA 600/2: 84-119.

Donnelly, J.A. Scarpino, P.V. andTabor, M.W.(1988). Clostridial presence in Harzardous waste-containing experimental landfills. In:Harzardous Waste Detection, Control, Treatment, Part B edited by R. Abbou Elsevier Science Pulishers,B.V. Amstardam, Printed in the Netherlands. 1073-1086.

Dupree, K.H. and Huner, J.V. (1984). The status of warm water fish farming and process in fish farming research. United State Fish and Widlife Services, Washington, D.C. USA.

Ehrig, H.J. (1983). Quality and Quantity of sanitary landfill leachate. Waste management and Research. 1 (1): 53-67.

Ernst, W.R., Hennigar, P., Doe, K., Wade, S. and Julien,G.(1994). Characterzation of the chemical constituents and toxicity to aquatic organisms of a municipal landfill leachate. Water Polluton Res.J. Can, 29(11): 89-101.

Ikem, A.,Osibanjo, O.,Sridhur, M.K.C. and Sobande, A.(2002).Evaluation of ground water quality characteristics near two waste sites in Ibadan and Lagos, Nigeria. Water-Air-Soil Pollut, 140, 307-333.

Koshy,L.,Paris, E.. Ling, S., Jones,T. and Berube, K. (2007). Bioreactivity of leachate From municipal solid waste landfills- assessment of toxicity. Sci. Total Environ., doi: 10.1016/j.scitotenv.2007.06.017.

McMurphy, L.M. Biradar,D.P., Taets,C. and Rayburn, A.L.(1996). Differential effects of weathered coal fly ash and fly ash leachate on maize genome. Arch. Environ. Contam. Toxicol.,31(2): 166-169.

Obbard, J.P. (1999). Landfill leachate: characterization and biology of treatment in Hong Kong, Res. Environ. Biotech, 2:235-248

Ojolo, S.J., Bamgboye, A.I., Aiyedun, P.O. and Ogunyemi, A.P (2004). Pyrolysis of shredded plastic waste. In: Proceedings of the $7^{\text {th }}$ Africa-America International conference on manufacturing Technology, Port-Harcourt, Nigeria. Vol. 1: 412-518.

Olutola,P.O., Famurewa, O. and Sonntag H.G. (et al.(2000). Measurement of microbial growth. In: An Introduction to General Microbiology, A Practical Approach. Bolabay Publications, Lagos, Nigeria. 78-122.

Ovre, S. and Adeniyi,H.A. (1990). A Simple Guide to Quality Management in Fish Pond. National Institute for Freshwater Fisheries Research Technical Report Series. No. 23: 29 pp.

Pillay,T.V.R. (1992). Environmental Impacts of cage culture for catfish in Chau Doc, Vietnam. Aquaculturecolloborative Research Support Program. Blackwell Scientific Publications Inc., Cambrigde, England.

Robinson, H.D. (1983). Problems of leachate from domestic waste tips in analysis for environmental protection. Annual Proceedings 20.

Van Vuren, J.H.J. (2006). The effects of toxicants on the haematology of Labeo umbratus (Teleostei: Cyprinidae). Comp.Biochem Physiol. C83(1):155-159.

Wick, A. and Dave, G. (2006). Acute Toxicity of leachates of tire wear materials to Daphnia magna- variability and toxic components. Chemosphere, 64: 1777-1784.

Wikipedia (2010) .Leachate. Wikipedia encyclopedia.

Wong, M.H. (1989). Toxicity test of landfill leachate using Sarotherodon mossambicus (freshwater fish). Ecotoxicol. Environ. Safety. 17(2): 149-156.

Yasuhara,A..Shraishi,H., Nishikawa, M., Yamamoto, T., Uehiro, T., Nakasugi,O.,Okumura, T.,Kenmotsu,K. Fukui, H. Nagase, M.,Ono,Y. Kawagoshi, Y.,Baba, K. and Noma, Y.(1997). Determination of organic components in leachate from hazardous waste disposal sites in Japan by gas chromatography-mass spectrometry. J.Chromatogr., A774: 321-332.

Yasuhara,A..Shraishi,H., Nishikawa, M., Yamamoto, T., Nakasugi,O.,Okumura, T.,Kenmotsu,K. Fukui, H. Nagase, M. and Kawagoshi, Y. (1999). Organic components in leachate from hazardous waste disposal sites, Waste Manage. Res., 17:186-197. 